GotTschalk, A. \& Fazekas de St Groth, S. (1960). J. gen. microbiol. 22, 690-697

\title{
On the Relationship between the Indicator Profile and Prosthetic Group of Mucoproteins Inhibitory for Influenza Virus Haemagglutinin
}

\author{
By A. GOTTSCHALK AND S. FAZEKAS DE ST GROTH \\ Department of Microbiology, John Curtin School of Medical Research, \\ Australian National University, Canberra
}

SUMMARY: The inhibitory titres of ovine and bovine submaxillary gland mucoproteins (OSM and BSM respectively), urinary mucoprotein, ovomucin and of the heat-stable seromucoid fraction of six animal species were determined under standard conditions against the same set of ten indicators derived from influenza viruses. By expressing relative rather than absolute titres 'indicator profiles' were obtained permitting direct comparison. OSM and BSM gave the most characteristic individual profiles and they closely resembled each other. Since the basic structures of the prosthetic groups of OSM and BSM are known to be identical, the close similarity of the profiles is regarded as resulting from this identity. A similar relationship seems to hold for the heat-stable mucoprotein fraction of various animal sera which have nearly identical profiles though distinctly different from the profile of the submaxillary mucoproteins.

Influenza viruses rendered non-infective by gentle heating still agglutinate red blood cells (Hirst, 1942), but in this state the viral haemagglutinin is readily inhibited by normal human and rabbit sera (Francis, 1947). This inhibitory effect was shown by McCrea (1948) to reside in the 'seromucoid' fraction (Rimington, 1940) and recognized by Burnet (1948) to be a property shared by a variety of mucinous materials of mammalian origin. Gottschalk \& Lind (1949) found in ovomucin, a mucoprotein fraction of egg-white, a potent and easily available virus haemagglutinin inhibitor. Electrophoretically homogeneous inhibitors were prepared from human urine (Tamm \& Horsfall, 1952) and from the secretions of the submaxillary glands of ox and sheep (Curtain \& Pye, 1955).

As to the chemistry of the inhibitory mucoproteins, the composition of the carbohydrate-prosthetic group of the homogeneous substances is well established (Table 1). Bovine and ovine submaxillary gland mucoproteins (BSM and OSM) have the simple disaccharide $6-\alpha-\mathrm{D}$-sialyl $(2 \rightarrow 6) N=$ acetylgalactosamine attached to the protein core (Gottschalk \& Graham, 1959; Graham \& Gottschalk, 1960). In the urinary inhibitor (UM) the prosthetic group is a small polysaccharide (m.w. about 12,000) (Gottschalk, 1952). Both types of mucoprotein have multiple prosthetic groups; in the salivary type 1 out of 7 amino acids carries such a group, in UM only 1 out of 300. Ovomucin (OM) consists of 3 mucoproteins which are closely similar in their physical properties; 2 of them act as inhibitors (Lanni, Sharp, Csaky \& Beard, 1950). The over-all analysis of their carbohydrate groups resembles that of UM (Table 1). Electrophoretic studies on the heat-stable human seromucoid fraction by Winzler, 
Devor, Mehl \& Smyth (1948) indicated the presence of three mucoproteins, all with low isoelectric points; their over-all carbohydrate analysis is given in Table 1.

Table 1. Carbohydrate analysis of some virus haemagglutinin inhibitory mucoproteins*

\begin{tabular}{|c|c|c|c|c|c|c|c|}
\hline & $\begin{array}{l}\text { Galac- } \\
\text { tose }\end{array}$ & Mannose & Fucose & $\begin{array}{l}\text { Glucos- } \\
\text { amine } \dagger\end{array}$ & $\begin{array}{l}\text { Galactos- } \\
\text { amine } \dagger\end{array}$ & $\begin{array}{l}\text { Sialic } \\
\text { acid } \ddagger\end{array}$ & References \\
\hline OSM & $\mathbf{0 . 3}$ & $0 \cdot 1$ & $0 \cdot 4$ & trace & $15 \cdot 0$ & $25 \cdot 4$ & $\begin{array}{l}\text { Graham \& } \\
\text { Gottschalk }\end{array}$ \\
\hline BSM & 0.7 & $0 \cdot 2$ & 0.7 & $2 \cdot 1$ & $12 \cdot 7$ & $22 \cdot 4$ & $\begin{array}{l}\text { Gottschalk \& } \\
\text { Graham (1959) }\end{array}$ \\
\hline UM & $5 \cdot 4$ & 2.7 & $1 \cdot 1$ & $7 \cdot 8$ & $1 \cdot 6$ & $9 \cdot 1$ & $\begin{array}{l}\text { Gottschalk } \\
\text { (1952); Odin } \\
\text { (1952) }\end{array}$ \\
\hline & $5 \cdot 4$ & $\mathbf{2 \cdot 7}$ & N.D. & $5 \cdot 7$ & 1.9 & 6.5 & Odin (1958) \\
\hline $\begin{array}{l}\text { Sero- } \\
\text { mucoid } \\
\text { (human) }\end{array}$ & $\begin{array}{r}1 \\
\text { (more } \\
\text { than } \mathrm{r}\end{array}$ & $\begin{array}{l}5 \cdot 1 \\
\text { galactose } \\
\text { nannose) }\end{array}$ & About 1 & $\begin{array}{r}1 \\
\text { (ms } \\
\text { gluco }\end{array}$ & $\begin{array}{l}1.9 \\
\text { ainly } \\
\text { samine) }\end{array}$ & ca. 11 & $\begin{array}{l}\text { Winzler et al. } \\
\text { (1948); Winzler } \\
\text { (1958) }\end{array}$ \\
\hline
\end{tabular}

The question then arose whether the chemical similarities and dissimilarities of the prosthetic groups were reflected in the biological activities of these mucoproteins. Qualitatively all inhibit appropriately treated influenza viruses ('indicator viruses', Stone, 1949). Quantitatively great dfferences may be observed when two mucoproteins are tested against one indicator, and no appreciable difference when tested against another one. Obviously the greater the variety of indicators used, the more detailed will be the biological definition of an inhibitor. By determining the inhibitory titres of individual mucoproteins against the same set of indicator viruses under standard conditions and by recording relative rather than absolute titres, strictly comparable 'indicator profiles' are obtained. In this paper indicator profiles are established for homologous and heterologous inhibitors and the results obtained viewed against the chemistry of their prosthetic groups.

\section{METHODS}

Inhibitory mucoproteins. BSM and OSM were prepared according to Gottschalk \& Graham (1959) and Graham \& Gottschalk (1960) respectively, UM according to Ada \& Gottschalk (1952) and OM according to Gottschalk \& Lind (1949). The seromucoid fraction of various animal species was prepared by diluting sera with an equal volume of buffer $(0.02 \mathrm{M}$-tris[hydroxymethyl]aminomethane-HCl, $0.15 \mathrm{M}-\mathrm{NaCl}$ and $\left.0.03 \mathrm{M}-\mathrm{CaCl}_{2}, \mathrm{pH} 7 \cdot 25\right)$, and heating at $\mathbf{7 2 . 5}^{\circ}$ for $30 \mathrm{~min}$. The precipitate formed was sedimented in an angle centrifuge, and the supernatant used.

Indicator viruses. Ten representative strains of influenza virus-WS (A) 
1933, PR 8 (A) 1934, MEL (A) 1935, BEL (A) 1942, CAM (A') 1946, FM 1 (A') 1947, LEE (B) 1940, BON (B) 1945, HUT (B) 1945, SW (swine) 1931-were grown in the allantois of 11-day chick embryos. The harvested fluids were tested for haemagglutinin content and those of high titre were pooled and transformed to indicator virus by the method of Stone (1949) in the modification described by Fazekas de St Groth (1952). Indicators are referred to as WS-i, PR 8-i, etc. By adding glycerol to such preparations (final glycerol concentration $33 \%, v / v)$, they can be kept at $-15^{\circ}$ for years without loss of titre.

Assay of inhibitory activity. Since each of the inhibitors was to be tested against the ten indicators, first a master set of twofold dilutions of the inhibitors was made up in $10 \mathrm{ml}$. volumes of isotonic saline. Then $0.25 \mathrm{ml}$. of each dilution was delivered into twenty cups of plastic trays (WHO model), giving duplicate rows for each of the ten indicators. Exactly four agglutinating doses of indicator were added to the appropriate rows from a calibrated dropping pipette, the trays shaken and left at room temperature for an hour. Each cup then received a standard drop $(0.025 \mathrm{ml}$.) of $5 \%$ red blood cells, and the patterns of agglutination were read 30 min later. Only cells of 'inhibitor sensitive' fowls (Anderson, 1948) were used, obtained as a rule on the day of testing. Partial agglutination was taken as the end-point, both in the adjustment of agglutinating doses and in the reading of the main test. The inhibitory titre refers, therefore, to that dilution of a sample at which, under the conditions of the standard test, 3 out of 4 agglutinating doses of an indicator virus are prevented from bridging red cells.

Tests of this kind are accurate to about $\pm 0.15 \log _{10}$ units. However, some combinations of inhibitor and indicator give flat endpoints, i.e. more than three twofold steps of partial agglutination patterns, thus reducing the accuracy. Such will be marked by an asterisk in Table 2 and by stippled columns in Fig. 1 .

Evaluation of experimental data. Each inhibitor was titrated in several standard tests against the same set of ten indicator viruses. From the results the geometric mean titre against each indicator was calculated; the common logarithm of the mean titre is the 'group mean'. The group means were averaged for each inhibitor, giving the 'overall mean'. The indicator profile of a particular mucoprotein is then defined as the plot of the differences [group mean minus over-all mean] on the ordinate against the series of indicators on the abscissa. The histogram showing the indicator profile is independent of the absolute magnitude of the titres and thus suitable for direct comparison of inhibitors. In fact the profile represents in graphical form the deviation of the inhibitory titre obtained with each indicator from a reference point. The over-all mean is preferable to any arbitrary reference point, since it is based on at least ten independent determinations and has therefore an error $\sqrt{ } \mathbf{1 0}$ times lower than any single value. The scatter of group means about the over-all mean is expressed as the mean distance, in $\log _{10}$ units, from this reference point and is referred to as 'average deviation'. 


\section{RESULTS}

The inhibitory titres of OSM, BSM, UM, OM and of the heat-stable seromucoid fraction from man, horse, ox, pig, rabbit and fowl are presented in Table 2. From the tabulated results the indicator profiles were obtained as described and are shown in Fig. 1.

\section{DISCUSSION}

Inhibition of influenza virus haemagglutination by mucoproteins is a phenomenon resulting from distribution of the indicator virus between two competing receptors, the mucoprotein and the receptor at the red cell surface. There is good evidence to show that the soluble mucoproteins are receptor analogues: both contain terminal substituted neuraminic acid residues, both are inactivated by neuraminidase, and efficient inhibitors have been prepared from red cell stroma (for reviews see Gottschalk, 1959). The distribution of a particle between two competitive receptors will depend on their relative concentrations and relative affinities for the particle. Since in a standard test the concentration of the cellular receptor as well as the concentration of the indicator virus is kept constant, and since end-points are always read at the same distribution ratio, the inhibitory titres of a mucoprotein, when tested against a series of indicators, are a direct measure of its relative affinities for these indicators. Equally, the inhibitory titres of two mucoproteins against the same indicator are an expression of their relative affinities for this indicator.

As may be seen from Fig. 1, the indicator profiles fall into three readily discernible groups. Most striking are the profiles of the two submaxillary mucoproteins exhibiting average deviations of 1.33 and 1.42 from the overall mean, i.e. 21- and 26-fold respectively in linear terms. Such marked differences in affinity of any one mucoprotein towards members of the chosen set of indicators would emphasize dissimilarities when comparing two profiles of this kind. Yet OSM and BSM show indistinguishable relative affinities towards eight of the ten indicators, the exceptions being Lee-i and SW-i.

In the group of seromucoids the average deviation from the over-all mean is significantly less (S/M 0.61, S/P 0.68, S/R 0.47, S/H 0.59, S/O 0.37, S/F 0.54, i.e. within the range of three- to fourfold) and uniform within this group. Again the profiles are indistinguishable at eight out of ten points, the discrepancies occurring with WSE-i and BEL-i.

In the third group, UM and OM, the average deviation from the over-all mean is still less $(0 \cdot 42$ and $0 \cdot 28$, i.e. $2 \cdot 6$ - and $1 \cdot 9$-fold respectively) resulting in a flat profile. Such differences as can be seen (Fig. 1) are within the error of the method. This uncharacteristic profile sets UM and OM apart from the other groups of inhibitors. Flat profiles tend to obscure any differences and hence their comparison has little meaning.

The close similarity of the sharp profiles of OSM and BSM argues strongly in favour of close similarity in their surface structures. In their basic structure the prosthetic groups of OSM and BSM are known to be identical (Gottschalk \& Graham, 1959; Graham \& Gottschalk, 1960); this may well account for the 
Table 2. Inhibitory activity of various mucoproteins against indicators derived from ten strains of influenza virus

\begin{tabular}{|c|c|c|c|c|c|c|c|c|c|c|c|c|c|}
\hline \multirow{2}{*}{\multicolumn{2}{|c|}{ Material }} & \multirow{3}{*}{$\begin{array}{l}\text { Symbol } \\
\text { OSM } \\
\text { BSM }\end{array}$} & \multicolumn{10}{|c|}{ Mean inhibitory titre against } & \multirow{2}{*}{$\begin{array}{r}\text { 'Over-all } \\
\text { mean' }\end{array}$} \\
\hline & & & WSE-i & PR8-i & MEL-i & BEL-i & CAM-i & FM1-i & LEE-i & BON-i & HUT-i & SW-i & \\
\hline $\begin{array}{l}\text { Submaxil- } \\
\text { lary gland } \\
\text { mucoprotein }\end{array}$ & $\begin{array}{l}\text { Sheep } \\
\text { Ox } \\
\text { n }\end{array}$ & & $\begin{array}{l}6 \cdot 16 \\
5 \cdot 68^{*}\end{array}$ & $\begin{array}{l}6 \cdot 44 \\
5.93\end{array}$ & $\begin{array}{l}\mathbf{3 \cdot 3 2} \\
\mathbf{2 \cdot 3 6}\end{array}$ & $\begin{array}{l}\mathbf{2 \cdot 8 9} \\
\mathbf{2 \cdot 2 8}\end{array}$ & $\begin{array}{l}\mathbf{2} \cdot 59 \\
\mathbf{2 \cdot 2 2}\end{array}$ & $\begin{array}{l}\mathbf{2 \cdot 7 6} \\
\mathbf{2 \cdot 3 1}\end{array}$ & $\begin{array}{l}5.45^{*} \\
2 \cdot 56\end{array}$ & $\begin{array}{l}5.68 \\
4.72\end{array}$ & $\begin{array}{l}5 \cdot 67 \\
4 \cdot 69\end{array}$ & $\begin{array}{l}4 \cdot 58 \\
2 \cdot 02\end{array}$ & $\begin{array}{l}4.55 \\
3 \cdot 48\end{array}$ \\
\hline $\begin{array}{l}\text { Urinary } \\
\text { mucoprotein }\end{array}$ & $n^{\text {Man }}$ & $\mathbf{U M}$ & 4.95* & $5 \cdot 80$ & 6.07 & $5 \cdot 37$ & 6.06 & $6 \cdot 47$ & 4.95 & $5 \cdot 36^{*}$ & $5 \cdot 27$ & $5 \cdot 76^{*}$ & $5 \cdot 61$ \\
\hline Ovomucin & Fowl & $\mathbf{O M}$ & 4.92 & $5 \cdot 62$ & $5 \cdot 47$ & 5.07 & $5 \cdot 32$ & $5 \cdot 54$ & 4.72 & $5 \cdot 13$ & 4.76 & $5 \cdot 45$ & $5 \cdot 20$ \\
\hline $\begin{array}{l}\text { Heat-stable } \\
\text { seromucoid } \\
\text { fraction }\end{array}$ & $\begin{array}{l}\text { Man } \\
\text { Pig } \\
\text { Rabbit } \\
\text { Horse } \\
\text { Ox } \\
\text { Fowl }\end{array}$ & $\begin{array}{l}\mathbf{S} / \mathbf{M} \\
\mathbf{S} / \mathbf{P} \\
\mathbf{S} / \mathbf{R} \\
\mathbf{S} / \mathbf{H} \\
\mathbf{S} / \mathbf{O} \\
\mathbf{S} / \mathbf{F}\end{array}$ & $\begin{array}{l}\mathbf{3 \cdot 8 4} \\
\mathbf{3 \cdot 9 3 ^ { * }} \\
\mathbf{3 \cdot 2 0 ^ { * }} \\
2 \cdot 87^{*} \\
2 \cdot 60^{*} \\
\mathbf{3 \cdot 8 4}\end{array}$ & $\begin{array}{l}\mathbf{2 \cdot 7 9} \\
\mathbf{3 \cdot 2 4} \\
\mathbf{2 \cdot 8 3} \\
\mathbf{2 \cdot 0 5} \\
\mathbf{2 \cdot 4 5 *} \\
\mathbf{3 \cdot 3 8}\end{array}$ & $\begin{array}{r}2.03 \\
1.83 \\
2.51 \\
<1.70 \\
<1.70 \\
\quad 2.18\end{array}$ & $\begin{array}{r}\mathbf{3 . 7 8} \\
\mathbf{3 . 9 7} \\
\mathbf{3 . 6 2} \\
\mathbf{1 . 8 5} \\
<\mathbf{1 . 7 0} \\
\mathbf{2 . 8 1}\end{array}$ & $\begin{array}{l}4 \cdot 26 \\
4 \cdot 94 * \\
3 \cdot 80 \\
2 \cdot 34 \\
1 \cdot 85 \\
3 \cdot 68\end{array}$ & $\begin{array}{l}\mathbf{5 \cdot 5 0} \\
\mathbf{5 \cdot 7 0} \\
\mathbf{4 \cdot 3 8} \\
\mathbf{4} \cdot 40 \\
\mathbf{2 \cdot 9 6} \\
\mathbf{5 \cdot 1 3}\end{array}$ & $\begin{array}{l}4 \cdot 26^{*} \\
4.79^{*} \\
3 \cdot 73^{*} \\
\mathbf{3 \cdot 2 0} \\
\mathbf{2 \cdot 4 5} \\
\mathbf{4 \cdot 0 3}\end{array}$ & $\begin{array}{l}\mathbf{3} \cdot 52 \\
3 \cdot 90 \\
3 \cdot 70 \\
2 \cdot 57 * \\
2 \cdot 00 \\
3 \cdot 48\end{array}$ & $\begin{array}{l}4 \cdot 02 \\
4 \cdot 16 \\
3 \cdot 14 \\
2 \cdot 33 \\
1 \cdot 85 \\
3 \cdot 71\end{array}$ & $\begin{array}{l}\mathbf{3 . 9 1} \\
4 \cdot 05 \\
2 \cdot 90 \\
1 \cdot 91 \\
1 \cdot 91 \\
\mathbf{3} \cdot 14\end{array}$ & $\begin{array}{r}\mathbf{3 . 7 9} \\
\mathbf{4 . 0 5} \\
\mathbf{3 \cdot 3 8} \\
\sim 2 \cdot 50 \\
\sim 2 \cdot 10 \\
\mathbf{3} \cdot 54\end{array}$ \\
\hline
\end{tabular}

The titres, expressed in $\log _{10}$ units, have errors of approximately $\pm 0 \cdot 15$; and those marked with * carry errors of about $\pm 0 \cdot 30$, since the end-points of their titrations were flatter. 
common features of the two profiles. The differences between OSM and BSM in their relative affinities for Lee-i and SW-i may reside either in the established differences in the substituents of their neuraminic acid residues (Gottschalk \& Graham, 1959; Graham \& Gottschalk, 1960) or in different distribution of their prosthetic groups along the polypeptide chains. The alternative of ascribing the near identity of the two profiles to practically identical protein moieties seems improbable because the two inhibitors come from different animal genera and since the amino acid composition of OSM was recently shown to be that of an ordinary metabolic protein (Gottschalk \& Simmonds, 1960).

If this reasoning is accepted, the similarity of profiles within the seromucoid group would suggest a commensurate similarity of the prosthetic groups. This inference accords with what little is known about the component sugars of the seromucoid fraction of man, ox and horse (Rimington, 1940; Rimington $\&$ van den Ende, 1940; Staub \& Rimington,1948; see also Table 1).

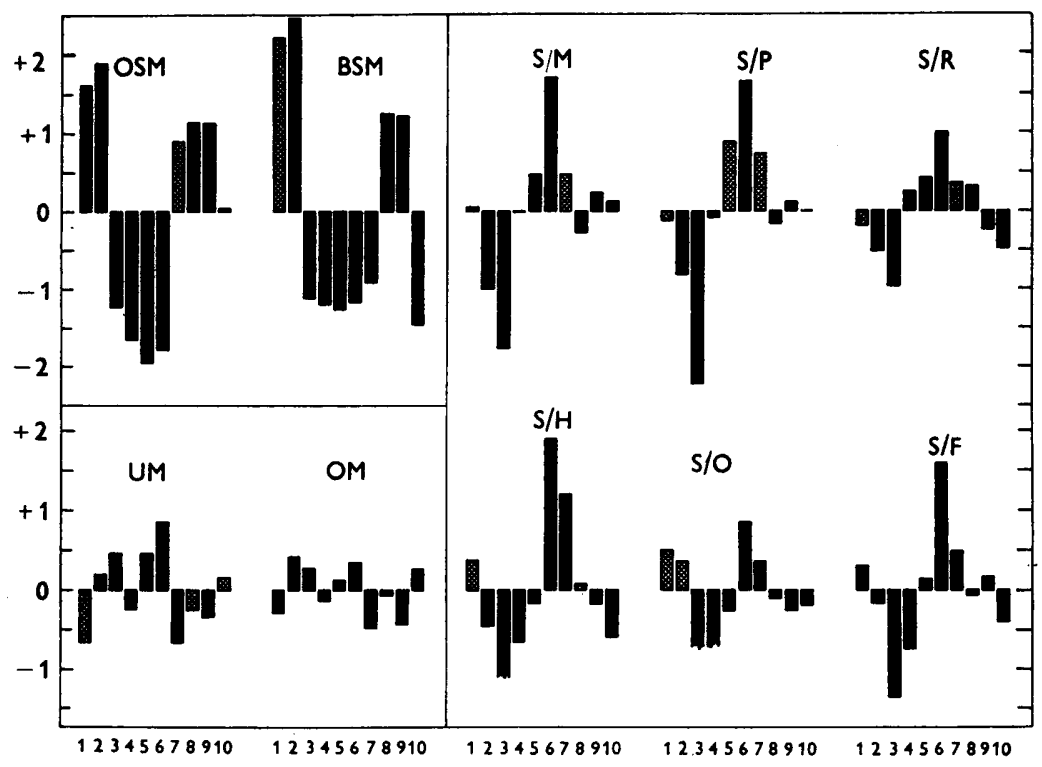

Fig. 1. Indicator profiles of various mucoproteins. The order of indicators, from left to right on the abscissa, is : 1, WSE-i; 2, PR 8-i ; 3, MEL-i; 4, BEL-i; 5, CAM-i ; 6, FM 1-i; 7, LEE-i; 8, BON-i; 9, HUT-i; 10, SW-i. The ordinate gives, in $\log _{10}$ units, the difference between the individual values and their 'over-all mean' taken from Table 2 . The stippled columns refer to the entries in Table 2 marked with an asterisk.

The carbohydrate moieties of UM and OM resemble each other as do their flat profiles. The question whether or not this is a coincidence has to be left open for the reason given above.

Mucoproteins with flat indicator profiles, though ill suited for discriminative comparison, are the preferred ones as inhibitors of viral haemagglutinins in biological work. Their uniform response to indicator viruses ensures unbiased results even when only one or two indicators are used in the test. By 
contrast, in biological work on mucoproteins with sharp profiles care must be taken when restricting the range of indicators.

It thus appears that sharp indicator profiles provide means to correlate chemical structure and biological activity of mucoproteins inhibiting influenza virus haemagglutination. Furthermore it is interesting that the high degree of biological specificity involved in the discrimination between various indicators is imparted to the protein, in the case of OSM and BSM, by simple disaccharides.

One of the authors (A.G.) was the recipient of a personal grant from the National Health and Medical Research Council of Australia.

\section{REFERENCES}

ADA, G. \& Gotrschatr, A. (1952). Preparation from urine of a pure substrate (mucoprotein) for the influenza virus enzyme. Aust. J. Sci. 14, 160.

Anderson, S. G. (1948). Mucins and mucoids in relation to influenza virus action. I. Inactivation by RDE and by viruses of the influenza group of the serum inhibitor of haemagglutination. Aust. J. exp. Biol. med. Sci. 26, 347.

Burnet, F. M. (1948). The initiation of cellular infection by influenza and related viruses. Lancet, $\mathrm{i}, \mathrm{t}$.

Curtain, C. C. \& Pye, J. (1955). A mucoprotein from bovine submaxillary glands with restricted inhibitory action against influenza virus haemagglutination. Aust. J. exp. Biol. med. Sci. 33, 315.

Fazeras de St Groth, S. (1952). Nasal mucus and influenza viruses. I. The haemagglutinin inhibitor in nasal secretions. J. Hyg., Camb. 50, 471.

Francis, T. (1947). Dissociation of the haemagglutinating and antibody-measuring capacities of influenza virus. J. exp. Med. 85, 1.

GotTschalk, A. (1952). Carbohydrate residue of a urine mucoprotein inhibiting influenza virus haemagglutination. Nature, Lond. 170, 662.

Gotrschalk, A. (1959). Chemistry of Virus Receptors. In The Viruses, Vol. 3, p. 51. Ed. F. M. Burnet \& W. M. Stanley. New York: Academic Press Inc.

GotTschalk, A. \& Graham, E. R. B. (1959). 6- $\alpha$-D-Sialyl-N-acetyl-galactosamine: the neuraminidase-susceptible prosthetic group of bovine salivary mucoprotein. Biochim. biophys. Acta, 34, 380.

Gottschalk, A. \& Lind, P. E. (1949). Ovomucin, a substrate for the enzyme of influenza virus. I. Ovomucin as an inhibitor of haemagglutination by heated Lee virus. Brit. J. exp. Path. 30, 85.

Gotrschalk, A. \& Simmonds, D. H. (1960). Studies on mucoproteins. II. Analysis of the protein moiety of ovine submaxillary gland mucoprotein. Biochim. biophys. Acta (in the Press).

Graham, E. R. B. \& Gotrschalk, A. (1960). Studies on mucoproteins. I. The structure of the prosthetic group of ovine submaxillary gland mucoprotein. Biochim. biophys. Acta, 38, 513.

Hirst, G. K. (1942). Adsorption of influenza haemagglutinins and virus by red blood cells. J. exp. Med. 76, 195.

Lanni, F., Sharp, D. G., Csáky, T. Z. \& Beard, J. W. (1950). The electrophoretic and biological complexity of ovomucin. Arch. Biochem. $28,313$.

McCrea, J. F. (1948). Mucins and mucoids in relation to influenza virus action. II. Isolation and characterization of the serum mucoid inhibitor of heated influenza virus. Aust. J. exp. Biol. med. Sci. 26, 355.

ODIN, L. (1952). Carbohydrate residue of a urine mucoprotein inhibiting influenza virus haemagglutination. Nature, Lond. 170, 663. 


\section{Indicator profiles of mucoproteins}

Odin, L. (1958). Mucopolysaccharides of epithelial mucus. In Chemistry and Biology of Mucopolysaccharides, p. 234. Ciba Foundation Symposium. London: Churchill.

Rimington, C. (1940). Seromucoid and the bound carbohydrate of the serum proteins. Biochem. J. 34, 931.

Rimington, C. \& VAN DEN Ende, M. (1940). Comparison of the globoglycoid, crystalbumin, seroglycoid and seromucoid fractions of normal horse serum. Biochem. J. 34, 941.

Staub, A. M. \& Rimington, C. (1948). Preliminary studies on the carbohydraterich fractions of ox serum. Biochem. J. 42, 5 .

STONE, J. D. (1949). Inhibition of influenza virus haemagglutination by mucoids. I. Conversion of virus to indicator for inhibitor. Aust. J. exp. Biol. med. Sci. 27, 337.

Tamm, I. \& Horsfall, F. L. (1952). A mucoprotein derived from human urine which reacts with influenza, mumps, and Newcastle disease viruses. J. exp. Med. 95, 71.

Winzuer, R. J. (1958). Glycoproteins of plasma. In Chemistry and Biology of Mucopolysaccharides, p. 245. Ciba Foundation Symposium. London: Churchill.

Winzler, R. J., Devor, A. W., Mehl, J. W. \& Smyth, I. M. (1948). Studies on the mucoproteins of human plasma. I. Determination and isolation. J. clin. Invest. 27, 609 . 